\title{
SIKAP PETANI ATAS PERALIHAN FUNGSI LAHAN PERTANIAN KE NON PERTANIAN DI KELURAHAN PASIR PUTIH, SAWANGAN, DEPOK
}

\section{Farmers Attitude over Land Conversion to Non Agricultural at Pasir Putih Village, Sawangan, Depok City}

\author{
Ratu Monita Citra Pratiwi ${ }^{1)}$, Anna Fatchiya
}

Departemen Sains Komunikasi dan Pengembangan Masyarakat, Fakultas Ekologi

Manusia, Institut Pertanian Bogor, Darmaga Bogor 16680, Indonesia

${ }^{1)}$ E-mail: pratiwi_ratu@apps.ipb.ac.id; annafa@apps.ipb.ac.id

\begin{abstract}
Attitude is an individual's reaction to an object that influenced by the stimulus. While the attitude of farmers over land conversion are encouragement from within farmers and reaction to change of land functions that they face. Purpose of this research is to analyze how farmers' attitudes land conversion to non-agriculture at Pasir Putih Village Sawangan Depok City and to identify factors that influence the emergence of these attitudes. This research uses quantitative methods that supported by qualitative data. This research was quantitative research with suvey method. Quantitative data supported by qualitatitve data. Quantitative method tested with a regression test and respondents selection by accidental techniques. The number of respondents in this research were 30 respondents. Results of this research is the farmers attitude land conversion to non-agriculture related land area change, shifting the profession, and income change has reached the stage of receiving and responding. The factors that influence farmers' attitudes over land conversion are internal and external factors. External factors are reflected by the availability of water, the selling price of land, and encouragement from outsiders.
\end{abstract}

Keywords: agricultural, attitude, farmers, land conversion.

\begin{abstract}
ABSTRAK
Sikap adalah reaksi individu terhadap suatu objek yang dipengaruhi adanya stimulus. Sementara sikap petani atas peralihan fungsi lahan adalah dorongan-dorongan dari dalam diri petani dan reaksi terhadap alih fungsi lahan yang mereka hadapi. Adapun tujuan dari penelitian ini adalah untuk menganalisis bagaimana sikap petani atas peralihan fungsi lahan kebun ke non pertanian di Kelurahan Pasir Putih Sawangan Depok dan mengidentifikasi faktor-faktor yang memengaruhi timbulnya sikap tersebut. Penelitian ini merupakan penelitian kuantitatif dengan metode survei. Data kuantitatif didukung dengan data kualiatif. Metode kuantitatif diuji dengan uji regresi dan pemilihan responden menggunakan teknik accidental. Jumlah responden dalam penelitian ini adalah 30 responden. Hasil penelitian ini menunjukkan bahwa sikap petani atas peralihan fungsi lahan pertanian ke non pertanian terkait perubahan luas lahan, peralihan profesi, dan perubahan pendapatan rata-rata sudah sampai tahap receiving dan responding. Selanjutnya faktor yang memengaruhi sikap petani atas peralihan fungsi lahan adalah faktor eksternal. Faktor eksternal dicerminkan oleh ketersediaan air, harga jual lahan, dan dorongan dari pihak luar.
\end{abstract}

Kata Kunci: alih fungsi lahan, pertanian, petani, sikap. 


\section{PENDAHULUAN}

Sumber daya alam yang dimiliki Indonesia sangat beragam seperti hutan, tanah, tumbuhan, dan air. Sumber daya alam tersebut berpotensi untuk meningkatkan kesejahteraan masyarakat. Lahan merupakan salah satu sumber daya alam yang dapat meningkatkan kesejahteraan masyarakat. Dalam bidang pertanian lahan menjadi sumber daya yang sangat penting, baik bagi petani maupun bagi pembangunan pertanian itu sendiri. Namun kini semakin banyak lahan yang semula ditujukan untuk aktivitas pertanian menjadi beralih fungsi.

Beberapa tahun terakhir peralihan fungsi lahan semakin marak terjadi. Data BPS menunjukkan bahwa luas baku lahan di Indonesia mengalami penurunan pada tahun 2018 seluas 7,1 juta hektar, dibanding dengan data tahun 2013 seluas 7,75 juta hektar. Aktifitas peralihan fungsi lahan banyak terjadi di lahan pertanian. Semakin tingginya aktivitas pembangunan industri yang terus terjadi memerlukan dukungan lahan sehingga menyebabkan lahan pertanian semakin berkurang. Pernyataan tersebut sesuai dengan penelitian Irawan (2005) yang menunjukkan bahwa aktivitas perubahan fungsi lahan lebih tinggi terjadi pada lahan sawah dibandingkan dengan lahan kering. Peralihan fungsi lahan yang terus terjadi disebabkan oleh berbagai hal diantaranya yakni tingginya harga jual lahan, peningkatan kebutuhan ekonomi, peningkatan jumlah penduduk, penurunan kualitas lahan, ketersediaan air, dan adanya sistem waris dalam keluarga petani.

Alih fungsi lahan yang terus terjadi menimbulkan dampak sosial, ekonomi bahkan budaya bagi masyarakat. Menurut Dewi dan Rudiarto (2013) konversi atau alih fungsi lahan pertanian berdampak pada terjadinya pergeseran struktur ketenagakerjaan, transformasi struktur ekonomi dari pertanian ke industri, pemilikan dan pengusaan lahan, dan juga mobilitas penduduk. Selanjutnya dalam aspek ekonomi alih fungsi lahan dapat mengurangi ketahanan pangan dan produksi sehingga masyarakat petani akan kehilangan pekerjaan. Berkaitan dengan hal tersebut dapat dikatakan adanya alih fungsi lahan berdampak langsung kepada petani.

Petani adalah aktor yang secara langsung ataupun tidak langsung terlibat dalam permasalahan alih fungsi lahan. Peralihan fungsi lahan berada di kehidupan mereka, sehingga menimbulkan penilaian petani terhadap alih fungsi lahan yang terjadi. Penilaian yang dimaksud berupa sikap petani tentang alih fungsi lahan yang terjadi. Sikap adalah kecenderungan, pandangan, pendapat atau pendirian seseorang untuk menilai suatu objek atau persoalan dan bertindak sesuai dengan penilaiannya dengan menyadari perasaan positif dan negatif dalam menghadapi suatu objek (Azwar, 2010). Tahapan individu dalam bersikap terhadap suatu stimulus dapat dilihat dengan indikator receiving, valuing, responding, organization, dan characterization by value of value complex (Bloom dalam Mugniesyah 2006).

Penilaian atau sikap yang dimiliki petani atas fenomena tersebut dipengaruhi oleh adanya faktorfaktor tertentu. Faktor-faktor yang diduga dapat memengaruhi sikap petani atas peralihan fungsi lahan yakni faktor internal dan faktor eksternal. Faktor internal dalam hal ini adalah sesuatu yang berasal dari dalam inidividu yakni karakteristik individu. Karakteristik individu dari petani berupa usia, tingkat pendidikan, tingkat pendapatan, luas lahan yang dimiliki, status pekerjaan bertani, dan jumlah tanggungan dalam keluarga. Selain itu juga faktor eksternal diduga dapat memengaruhi sikap petani atas peralihan fungsi lahan pertanian. Faktor eksternal yakni sesuatu hal yang memengaruhi sikap yang berasal dari luar diri petani. Faktor eksternal yang dapat memengaruhi berupa ketersediaan air, harga jual lahan, dan dorongan dari pihak luar. Stimulus yang berasal dari luar kemungkinan dapat mendorong sikap petani atas peralihan fungsi lahan pertanian ke non pertanian.

Salah satu wilayah di Kota Depok, Jawa Barat yang mengalami alih fungsi lahan yakni Kelurahan Pasir Putih, Kecamatan Sawangan. Kelurahan Pasir Putih adalah salah satu wilayah potensi pertanian yang dimiliki Kota Depok. Sistem pertanian yang dilakukan di Kelurahan Pasir Putih menerapkan sistem seperti pertanian perkotaan. Kelurahan Pasir Putih menjadi salah satu wilayah produsen Belimbing Dewa yang dahulunya sempat menjadi icon Kota Depok. Akan tetapi beberapa tahun terakhir di kelurahan tersebut justru semakin banyak pembangunan di atas lahan pertanian. Lahan yang dahulunya ditujukan 
untuk pertanian kini beralih fungsi.

Kegiatan alih fungsi lahan yang terjadi memberikan pengaruh bagi kehidupan petani. Salah satu pengaruhnya yakni dampak yang terjadi seperti pendapatan petani, kehilangan mata pencaharian. Menurut Rahmawat (2012) adanya alih fungsi lahan menghadapkan petani pada situasi sulit dalam menentukan pilihan untuk keberlanjutan hidupnya. Di satu sisi, harga lahan yang tinggi membuat petani tergiur untuk menjual lahannya. Di sisi lain, buruh tani akan terancam kehidupannya saat lahan dijual, karena kehilangan sumber penghidupannya. Oleh karena itu peneliti tertarik menganalisis sikap petani atas peralihan fungsi lahan pertanian ke non pertanian.

\section{PENDEKATAN TEORITIS}

\section{Konsep Sikap}

Sikap adalah pernyataan evaluasi terhadap suatu objek berupa benda ataupun peristiwa. Menurut Azwar (2010) sikap adalah kecenderungan, pandangan, pendapat atau pendirian seseorang untuk menilai suatu objek atau persoalan dan bertindak sesuai dengan penilaiannya dengan menyadari perasaan positif dan negatif dalam menghadapi suatu objek.

Baron dan Bryne (2003) menjelaskan sikap adalah evaluasi seseorang terhadap berbagai aspek dan evaluasi tersebut memunculkan rasa suka atau tidak suka terhadap isu, ide, orang, kelompok sosial, dan objek. Sikap memiliki tiga komponen di dalamnya. Tiga komponen sikap tersebut yakni komponen kognisi (ide, konsep, persepsi, dan pengetahuan), komponen afeksi (emosional, perasaan), dan komponen konasi (tingkah laku). Ketiga komponen sikap tersebut merupakan tahapan individu dalam memberi respon atau tanggapan pada stimulus yang didapat. Pengetahuan individu tentang suatu objekstimulus tersebut akan menimbulkan perasaan tertentu yang akan mendorong seseorang untuk bertindak terhadap stimulus tersebut.

Sikap sendiri terdapat beberapa tahapan dalam merespon stimulus yang didapatnya. Respon pada stimulus bisa berupa positif dan negatif. Selain memiliki tiga komponen yang sudah dijelaskan oleh Baron dan Bryne, sikap juga memiliki tahapan yang dijelaskan dalam Taksonomi Bloom. Tahapan dalam bersikap menurut Bloom dalam Mugniesyah (2006) berupa: (1) Receiving (penerimaan): Meliputi kepekaan akan adanya suatu perangsang (stimuli) dan kesediaan untuk memperhatikan rangsangan tersebut; (2) Responding (menanggapi), Meliputi kerelaan untuk memperhatikan secara aktif dan berpartisipasi dalam suatu kegiatan; (3) Valuing (penilaian atau penentuan sikap) Meliputi kemampuan untuk memberikan penilaian terhadap sesuatu dan membawa diri sesuai dengan penilaian; (4) Organization (pengorganisasian), Meliputi kemampuan untuk membentuk suatu sistem nilai sebagai pedoman dan pegangan dalam kehidupan; dan (5) Characterization by value of value complex (menghayati), Pembentukan pola hidup mencakup kemampuan untuk menghayati nilai-nilai kehidupan sedemikian rupa, sehingga menjadi milik pribadi (internalisasi) dan menjadi pegangan nyata dan jelas dalam mengatur kehidupannya sendiri.

\section{Alih Fungsi Lahan}

Lahan merupakan bagian daratan pada permukaan bumi. Keberadaannya yang sangat berguna bagi kehidupan manusia menjadikan penggunaan lahan dapat berubah-ubah. Menurut Saefulhalim (1995) penggunaan lahan merupakan suatu proses yang dinamis, sebagai hasil dari perubahan pada pola dan besarnya aktivitas manusia sepanjang waktu. Oleh karena itu, masalah yang berkaitan dengan lahan merupakan masalah yang kompleks. Permasalahan tersebut berdampak pada upaya pemanfaatan sumberdaya lahan yang optimal memerlukan alokasi penggunaan lahan yang efisien.

Aktivitas lahan yang terancam perubahan pemanfaatannya banyak terjadi di lahan pertanian. Perkembangan industri ini membutuhkan dukungan lahan, sehingga menyebabkan lahan pertanian semakin sempit. Pernyataan tersebut dibuktikan pada penelitian Irawan (2005) yang melakukan penelitian pada lahan sawah menyatakan bahwa peluang terjadinya konversi lahan sawah lebih tinggi dibandingkan dengan lahan kering. 
Alih fungsi lahan atau konversi lahan adalah perubahan fungsi sebagian atau keseluruhan lahan dari fungsi semula menjadi fungsi lain yang membawa dampak negatif terhadap lingkungan dan potensi yang dimiliki lahan tersebut (Lestari 2009). Alih fungsi lahan merupakan permasalahan yang sangat bersinggungan dengan kehidupan petani.

Alih fungsi lahan yang terjadi sebagian besar disebabkan oleh faktor sosial dan ekonomi. Menurut (Ridwan 2009) alih fungsi lahan yang dilakukan oleh petani karena kebutuhan ekonomi dan harga lahan yang tinggi. Berdasarkan hal tersebut dapat dikatakan bahwa penyebab alih fungsi lahan diantaranya, yakni adanya desakan kebutuhan ekonomi dan didukung oleh harga jual lahan yang tinggi. Selain itu alih fungsi lahan juga terjadi karena kualitas lahan yang sudah tidak memungkinkan untuk digunakan kegiatan pertanian.

Alih fungsi lahan yang terjadi menimbulkan permasalahan baru pada sektor pertanian. Alih fungsi lahan yang terjadi dapat memberi dampak kepada pemilik lahan, buruh tani, serta masyarakat yang tinggal di sekitar lahan. Alih fungsi lahan yang terjadi dapat memengaruhi sosial ekonomi petani pemilik lahan sekaligus buruh tani. Hal tersebut berdampak kehilangan pekerjaan pada buruh tani dan pendapatannya menurun. Selain itu alih fungsi lahan yang terjadi dapat mengurangi ketahanan pangan bagi produksi pertanian. Permasalahan dampak dari alih fungsi lahan yang terjadi sesuai dengan penelitian Kusdiane et al (2018) di Pandeglang menyatakan bahwa terjadinya alih fungsi lahan juga berdampak pada budaya masyarakat yang bergeser. Selanjutnya menurut penelitian Dewi \& Rudiarto (2013) di Semarang menyatakan bahwa konversi atau alih fungsi lahan pertanian berdampak pada pergeseran struktur ketenagakerjaan, transformasi struktur ekonomi dari pertanian ke industri, pemilikan dan pengusaan lahan, juga mobilitas penduduk. Selanjutnya pada aspek ekonomi akan mengurangi ketahanan pangan dan produksi sehingga masyarakat petani akan kehilangan pekerjaan.

\section{Faktor-faktor yang Memengaruhi Sikap Petani atas Peralihan Fungsi Lahan}

Faktor-faktor yang memengaruhi sikap petani atas peralihan fungsi lahan dapat diidentifikasikan menjadi dua yakni faktor eksternal dan faktor internal. Faktor-faktor internal yang memengaruhi sikap petani atas peralihan fungsi lahan, yaitu: (1) Umur, Usia dapat memengaruhi sikap seseorang. Pernyataan ini sesuai dengan penelitian Rahmawati (2012) yang menyatakan bahwa semakin tua usia petani pengetahuan mengenai alih fungsi lahan semakin rendah. Kemudian sebaliknya dengan semakin muda usia petani maka pengetahuan tentang alih fungsi lahan semakin tinggi. Berdasarkan hal tersebut menunjukkan bahwa usia petani dapat memengaruhi sikap petani tetang alih fungsi lahan pertanian ke non pertanian; (2) Lama Pendidikan, Lama pendidikan formal yang ditempuh oleh seseorang dapat memengaruhi sikap seseorang. Pernyataan ini sesuai dengan penelitian Rahmawati (2012) yang menyatakan bahwa semakin tinggi tingkat pendidikan petani maka tingkat pengetahuan tentang alih fungsi lahannya juga semakin tinggi. Berdasarkan hal tersebut menunjukkan bahwa lama pendidikan dapat memengaruhi sikap petani tentang alih fungsi lahan pertanian ke non pertanian; (3) Tingkat pendapatan, Pendapatan merupakan upah dan gaji atas jam kerja atau pekerjaan yang telah diselesaikan, upah lembur, semua bonus dan tunjangan, perhitungan waktu tidak bekerja, bonus yang dibayarkan tidak teratur, penghargaan dan nilai pembayaran sejenisnya (BPS 2019). Penelitian Rahmawati (2012) menunjukkan bahwa semakin tinggi tingkat pendapatan maka semakin tinggi tingkat pengetahuan petani tentang alih fungsi lahan. Pernyataan tersebut menunjukkan bahwa tingkat pendapatan dapat juga memengaruhi sikap petani tentang alih fungsi lahan pertanian ke non pertanian; (4) Jumlah tanggungan dalam keluarga, Bagian ini berkaitan dengan besar kecilnya jumlah tanggungan dalam keluarga. Penelitian Sarayar et. al (2016) menunnjukkan bahwa jumlah konsumsi keluarga seiring dengan kebutuhan ekonomi yang semakin besar cenderung menjadi penyebab dari semakin meningkatnya peralihan fungsi lahan. Berdasarkan penelitian tersebut sehingga dapat dikatakan bahwa jumlah tanggungan keluarga memiliki pengaruh dalam sikap petani tentang alih fungsi lahan pertanian ke non pertanian; 
(5) Luas lahan yang dikuasai, Luas lahan yang dikuasai adalah luas lahan yang dimiliki dan juga luas lahan yang disewa oleh petani. Kemudian untuk mendapatkan nilai luas lahan yang dikuasai yakni dengan menjumlahkan seluruh luas lahan yang dikuasai oleh petani, baik sewa ataupun milik pribadi. Luas penguasaan lahan akan memengaruhi produksi dan pendapatan yang diperoleh, selain itu melihat bagaimana efisiensi pengelolaan lahannya, sehingga luas lahan yang dikuasai dapat memengaruhisikap petani atas peralihan fungsi lahan. Dengan kata lain, luas penguasaan lahan kemungkinan dapat memengaruhi sikap petani atas peralihan fungsi lahan pertanian ke non pertanian; (6) Jarak lokasi lahan dengan jalan utama, Jauh atau dekatnya lokasi lahan pertanian dengan jalan utama dapat memengaruhi sikap petani tentang alih fungsi lahan. Hal tersebut ditunjukkan pula pada teori Van Thunen dalam Siswanto (2007) yang menyatakan bahwa semakin dekat lokasi lahan dengan pusat keramaian maka semakin tinggi nilai lahan tersebut. Oleh karena itu diperlukan pengalokasian lahan pertanian atau dikenal dengan konsep lahan sawah abadi. Hal tersebut dilakukan untuk menghindari alih fungsi lahan pertanian menjadi sektor industri. Berdasarkan pernyataan dari teori tersebut maka dapat dikatakan jarak lokasi lahan pertanian dengan jalan utama dapat memberikan pengaruh pada sikap petani tentang alih fungsi lahan pertanian ke non pertanian.

Faktor eksternal yang memengaruhi sikap petani tentang alih fungsi lahan yakni: (1) Ketersediaan air dalam pengairan lahan pertanian dapat memengaruhi sikap petani tentang alih fungsi lahan. ketersediaan air atau permaslaahn irigasi menjadi faktor eksternal terjadinya alih fungsi lahan. Kondisi alam juga sangat memengaruhi masa penanaman, karena jika pengairan tidak berjalan semestinya, petani akan bergantung dengan cuaca; (2) Harga jual lahan yang semakin tinggi dapat memengaruhi sikap petani tentang alih fungsi lahan. Selain itu nilai jual lahan di setiap lokasi dan daerah berbeda. Siswanto (2007) menyatakan bahwa pusat kota sebagai daerah yang memiliki aksesibilitas tinggi memiliki nilai lahan yang tertinggi. Selain di pusat kota, nilai lahan tertinggi kedua adalah Kawasan yang berada di jalan arteri sekunder. Harga jual lahan yang tinggi dapat mendorong petani untuk menjual lahannya, sehingga harga jual lahan memengaruhi sikap petani tentang alih fungsi lahan; dan (3) Dorongan dari pihak luar, Dorongan dari pihak luar dapat memengaruhi sikap seseorang. Dorongan dari pihak luar ini berupa beberapa alasan petani ingin menjual lahannya atau mengubah fungsi lahan. berdasarkan penelitian menyatakan bahwa alasan petani menjual lahan adalah harga lahan, dorongan keluarga, desakan industri, desakan pihak perumahan, dan untuk keperluan tertentu. Selain dorongan dari pihak luar dapat juga berasal dari petani lain dan calo, pihak yang menjadi pihak ketiga dalam menjual lahan. Berdasarkan pernyataan tersebut dorongan dari pihak luar dapat memengaruhi sikap petani tentang alih fungsi lahan.

\section{PENDEKATAN LAPANG}

Penelitian ini menggunakan pendekatan penelitian kuantitatif dengan metode survei dan dikuatkan dengan data kualitatif. Pendekatan kuantitatif melalui metode survei yaitu informasi dikumpulkan dari responden dengan menggunakan kuesioner. Pengumpulan data kualitatif dilakukan dengan cara wawancara mendalam menggunakan panduan pertanyaan. Data kualitatif yang didapatkan berperan untuk mendukung dan sebagai interpretasi terhadap data kuantitatif.

Penelitian ini dilaksanakan di Kelurahan Pasir Putih, Kecamatan Sawangan, Kota Depok, Jawa Barat. Pemilihan lokasi ini dilakukan secara sengaja (purposive) karena Kelurahan Pasir Putih merupakan salah satu wilayah di Kota Depok yang lahan pertaniannya masih cukup luas dan mayoritas masyarakat aslinya bekerja sebagai petani. Selain itu juga berdasarkan data BPS menunjukkan bahwa dalam saktu dua tahun, 2014-2016 luas lahan pertanian di Kelurahan Pasir Putih mengalami penurunan.

Subjek dalam penelitian ini adalah responden dan informan. Populasi dari penelitian ini adalah petani di Kelurahan Pasir Putih, Kecamatan Sawangan, Kota Depok. Responden dari penelitian ini adalah petani yang masih aktif hingga Januari 2020. Petani dalam penelitian ini didefinisikan dengan seseorang yang sumber pendapatan utamanya berasal dari aktivitas pertanian. Oleh karena itu unit analisis penelitian ini adalah individu, yakni petani. 
Hal tersebut dikarenakan hadirnya fenomena alih fungsi lahan pertanian ke non pertanian di wilayahnya para petani inilah yang terdampak dan/atau terlibat secara langsung maupun tidak langsung dalam fenomena tersebut. Populasi keseluruhan dari penelitian ini berjumlah 105 petani jika berdasarkan Data Demografi Kelurahan Pasir Putih, Kecamatan Sawangan, Depok tahun 2019. Akan tetapi saat peneliti mewawancarai dua ketua kelompok tani menyatakan bahwa anggota dari kelompok tani masing-masing berjumlah 20 orang dan 10 orang. Selain itu juga saat di lapang terdapat petani yang tidak bergabung dalam kelompok tani dan juga terdapat petani yang tidak bersedia untuk diwawancarai. Berdasarkan hal tersebut teknik pemilihan responden yang digunakan adalah accidental sampling, yakni sebuah sampel yang heterogen diambil sedemikian rupa sehingga tiap unit penelitian atau satuan elementer dari populasi mempunyai kesempatan yang sama untuk dipilih sebagai sampel (Singarimbun 1989). Oleh karena itu responden dari penelitian ini berjumlah 30 orang petani yang dapat ditemui saat proses penelitian dan bersedia untuk diwawancara.

Data yang digunakan dalam penelitian ini adalah data primer dan data sekunder. Data primer merupakan data yang diperoleh secara langsung oleh peneliti di lokasi penelitian melalui penyebaran kuesioner kepada responden, dan wawancara mendalam dengan responden dan informan, serta observasi pengamatan langsung di lapangan. Data sekunder adalah data yang dapat diperoleh dari lembaga terkait, seperti BPS dan Dinas Pertanian Kota Depok. Selain itu data sekunder juga diperoleh dari kajian pustaka yang berupa jurnal dan buku serta analisis literatur lainnya yang berkaitan dengan penelitian.

Selanjutnya untuk jenis data yang dimiliki oleh penelitian ini adalah data kuantitatif dan data kualitatif. Data yang diperoleh secara kuantitatif berupa data yang diperoleh dari jawaban reponden atas kuesioner, sementara data kualitatif didapat dari jawaban responden dan informan atas pertanyaan tertruktur pada panduan pertanyaan. Kedua data tersebut kemudian diolah, data kuantitatif akan diolah menggunakan Microsoft Excel 2010, IBM SPSS Statistics 23 for Windows, dan Partial Least Square (PLS) versi Smart PLS 3. Data responden didapatkan dari hasil pembuatan tabel frekuensi dan kategori dengan menggunakan Microsoft Excel 2010 dan SPSS Statistics 23 for Windows. PLS digunakan untuk membantu dalam uji regresi linear berganda. Pengolahan data disajikan dalam bentuk Tabel dan gambar (hasil uji regresi) dan dijelaskan dengan data kuantitatif deskriptif. Kemudian data kualitatif dianalisis dengan merangkum hasil wawancara mendalam dengan para responden dan informan dengan melakukan proses pemilihan dan penyederhanakan data hasil wawancara mendalam, lalu menyusun informasi dan data yang diperoleh menjadi serangkaian kata-kata atau narasi yang mudah dibaca ke dalam sebuah laporan, lalu melakukan verifikasi, yaitu penarikan kesimpulan dari hasil yang telah diolah untuk mendukung data kuantitatif.

\section{HASIL DAN PEMBAHASAN}

\section{Faktor Internal}

Karakteristik petani yang menjadi responden di Kelurahan Pasir Putih dalam penelitian ini menjadi factor internal menunjukkan bahwa petani di kelurahan tersebut adalah berjenis kelamin laki- laki. Mayoritas petani yang menjadi responden memiliki rentang usia 45 tahun hingga 55 tahun. Petani yang menjadi responden di Kelurahan Pasir Putih mayoritas menempuh pendidikan sampai pada tingkat SMA, namun sangat sedikit yang menempuh pendidikan hingga perguruan tinggi. Luas lahan yang dikuasai mayoritas petani seluas kurang dari $3.349 \mathrm{~m}^{2}$. Pendapatan yang diperoleh petani kebanyakan pada rentang Rp. 36.293 .406 hingga Rp. 95.367.926. Mayoritas petani di Kelurahan Pasir Putih memiliki jumlah tanggungan sebanyak dua sampai empat orang. Selain itu diperoleh juga fakta lain yakni mayoritas petani di Kelurahan Pasir Putih lahan yang dikuasainya berstatus milik sendiri, akan tetapi terdapat sebagian kecil dari petani tersebut lahan yang dikuasainya adalah sewa. Jarak lokasi lahan yang dikuasai oleh petani mayoritas juga tidak terlalu jauh dari jalan utama kelurahan, yakni sekitar $154 \mathrm{~m}$ hingga $1.096 \mathrm{~m}$ menuju jalan utama kelurahan. 


\section{Faktor Eksternal}

Tingginya angka peralihan fungsi lahan yang terjadi di lingkungan petani menimbulkan sikap petani terhadap fenomena yang terjadi. Sikap petani tersebut dipengaruhi juga oleh faktor eksternal. Faktor eksternal adalah hal-hal yang berasal dari luar diri petani yakni dari lingkungan dan orang di sekitarnya. Faktor eksternal yang diperhatikan pada penelitian ini adalah ketersediaan air, harga jual lahan, dan dorongan dari pihak luar.

Berkaitan dengan ketersediaan air, di Kelurahan Pasir Putih sudah tidak lagi memiliki saluran irigasi. Aktivitas pertanian di Kelurahan Pasir Putih, sempat memiiliki saluran irigasi. Hal tersebut dikarenakan wilayah Kelurahan Pasir Putih sempat ingin dijadikan RTH dari Kota Depok. Putusnya saluran irigasi di Kelurahan Pasir Putih membuat banyak petani harus mengganti jenis komoditas yang ditanami. Petani harus memilih jenis komoditas yang tidak memelukan banyak air, seperti belimbing.

Selanjutnya berkaitan dengan harga jual lahan, lahan pertanian di Kelurahan Pasir Putih terus mengalami peningkatan harga. Berdasarkan wawancara dengan responden dan informan, hal tersebut terjadi disebabkan oleh lokasi Kelurahan Pasir Putih sudah termasuk area perkotaan sehingga biaya pajak dan NJOP mengalami kenaikan. Selain itu harga jual lahan yang terus meningkat disebabkan sudah semakin banyak lahan sekitar yang terjual dan dibangun untuk pemukiman seperti perumahan, kemudian didukung dengan fasilitas sarana dan prasarana yang semakin lengkap. Hal tersebut terjadi didukung pula oleh tawaran dari berbagai developer ataupun calo kepada para pemilik lahan.

Kemudian mengenai dorongan dari pihak luar, berdasarkan wawancara dengan responden menyatakan bahwa mayoritas dari mereka banyak mendapatkan tawaran dari pihak luar seperti developer atau calo untuk menjual lahannya. Akan tetapi tidak ada satupun dari mereka yang menerima tawaran tersebut. Alasan dari mereka sendiri memilih untuk terus bertahan menjadi petani yakni karena keterbatasan keterampilan yang dimiliki dan merasa pendapatan yang diperoleh dari Bertani sudah mampu mencukupi. Selain itu juga keseluruhan dari mereka mendapatkan motivasi dan dukungan darikeluarga untuk terus Bertani karena mayoritas dari mereka berasal dari keluarga petani.

\section{Sikap Petani atas Peralihan Fungsi Lahan}

Alih fungsi lahan yang terjadi di Kelurahan Pasir Putih menimbulkan sikap yang beragam dari para petani di wilayah tersebut yang masih bertahan hingga sekarang. Sikap petani atas peralihan fungsi lahan pertanian ke non pertanian diukur menggunakan taksonomi Bloom yakni dengan indikator receiving, responding, valuing, dan organization. Hal yang menjadi stimulus pada penelitian adalah alih fungsi lahan mengenai perubahan luas lahan, peralihan profesi, dan perubahan pendapatan.

Setelah melakukan wawancara dengan responden dan pengukuran kuesioner mengenai sikap petani terhadap perubahan luas lahan, membuktikan bahwa keseluruhan petani memiliki tahap receiving yang paling tinggi dari empat tahapan sikap. Berdasarkan hasil pengukuran tersebut dapat dikatakan petani di Kelurahan Pasir Putih yang masih bertahan sudah menerima terjadinya perubahan luas lahan yang terjadi di wilayahnya. Akan tetapi sebagian besar dari mereka tidak menyetujui hal tersebut terjadi di wilayahnya. Meskipun terdapat sebagian dari mereka yang pernah menjual sebagian dari lahan yang dimiliki, akan tetapi sebenarnya mereka tidak ingin hal tersebut terjadi namun karena kebutuhan yang mendesak mereka untuk melakukan hal demikian. Sebagian besar dari mereka juga belum pernah sebelumnya melakukan mengubah fungsi lahannya. 
Tabel 1 Rerataan tahapan sikap petani terhadap perubahan luas lahan di Kelurahan Pasir Putih pada tahun 2020

\begin{tabular}{lc}
\hline $\begin{array}{l}\text { Tahapan } \\
\text { sikap pada } \\
\text { perubahan }\end{array}$ & $\begin{array}{c}\text { Rata } \\
\text { an }\end{array}$ \\
$\underline{\text { luas lahan }}$ & \\
\hline $\begin{array}{l}\text { Receiving } \\
\text { Responding }\end{array}$ & 7.2 \\
Valuing & 6.3 \\
Organizatio & 3.2 \\
$n$ & 3.4 \\
\hline
\end{tabular}

Selanjutnya terkait sikap petani terhadapf peralihan profesi, pengukuran kuesioner hasil jawaban responden menunjukkan bahwa tahapan sikap petani terhadap peralihan profesi paling tinggi yakni pada tahap receiving. Berkaitan dengan hal itu dapat dikatakan, petani di wilayah Kelurahan Pasir Putih mengetahui dan menyadari bahwa di lingkungan cukup banyak petani yang beralih profesi dan jumlah petani semakin sedikit. Akan tetapi hal tersebut tidak membuat mereka berpikir untuk berhenti bertani. Semakin banyak petani yang beralih profesi juga tidak terlalu bermasalah menurut mereka, karena menurutnya kebutuhan ekonomi masing-masing individu berbeda sehingga cara untuk memenuhinya pun juga berbeda.

Tabel 2 Rataan tahapan sikap petani terhadap peralihan profesi di Kelurahan Pasir Putih pada tahun 2020

\begin{tabular}{lc}
\hline $\begin{array}{l}\text { Tahapan } \\
\text { sikap pada }\end{array}$ & $\begin{array}{c}\text { Rata } \\
\text { an }\end{array}$ \\
- & \\
\hline peralihan & \\
profesi & \\
\hline Receiving & \\
Responding & 6.8 \\
Valuing & 4.2 \\
Organizatio & 3.2 \\
$n$ & 3.2 \\
\hline
\end{tabular}

Selanjutnya, berdasarkan wawancara dan pengukuran kuesioner mengenai sikap petani terhadap perubahan pendapatan, dibuktikan bahwa tahapan sikap petani terhadap perubahan pendapatan paling tinggi mencapai tahapan receiving. Petani di Kelurahan Pasir Putih mengetahui perubahan pendapatan jika bekerja di non pertanian. Meskipun mayoritas dari mereka belum pernah mencoba bekerja di non pertanian, tetapi mereka tetap merasa pendapatan sebagai petani lebih menguntungkan. Walaupun bekerja sebagai petani jumlah pendapatannya tidak menentu dan sangat bergantung dengan cuaca. 
Tabel 3 Rataan tahapan sikap petani terhadap perubahan pendapatan di Kelurahan Pasir Putih pada tahun 2020

\begin{tabular}{lc}
\hline $\begin{array}{l}\text { Tahapan } \\
\text { sikap pada } \\
\text { perubahan }\end{array}$ & $\begin{array}{c}\text { Rata } \\
\text { an } \\
\text { pendapatan }\end{array}$ \\
\hline Receiving & \\
Responding & \\
Valuing & 5.3 \\
Organization & 4.6 \\
\hline
\end{tabular}

\section{Faktor-faktor yang Memengaruhi Sikap Petani atas Peralihan Fungsi Lahan}

Fenomena peralihan fungsi lahan pertanian ke non pertanian menimbulkan sikap para petani sebagai pihak yang kehidupannya bersinggungan dengan lahan pertanian. Sikap petani atas peralihan fungsi lahan (Y) dipengaruhi oleh faktor internal (X1) dan faktor eksternal (X2). Faktor-faktor yang memengaruhi sikap petani atas peralihan fungsi lahan diuji menggunakan Partial Least Square (PLS).

Tabel 4 Nilai signifikansi variabel berdasarkan path coefficient dan T-Values

\begin{tabular}{lccl}
\hline Pengaruh & $\begin{array}{l}\text { Path } \\
\text { coefficient }\end{array}$ & $\begin{array}{l}\text { T- } \\
\text { values }\end{array}$ & Signifikansi \\
\hline $\begin{array}{l}\text { Faktor } \\
\text { internal }\end{array}$ & $-0,192$ & 0,777 & $\begin{array}{l}\text { Tidak } \\
\text { Signifikan }\end{array}$ \\
$\begin{array}{l}\text { P Sikap } \\
\text { petani }\end{array}$ & & & \\
$\begin{array}{l}\text { Faktor } \\
\text { eksternal } \\
\text { => Sikap } \\
\text { petani }\end{array}$ & 0,538 & 2,879 & Siginifikan \\
\hline
\end{tabular}

Tabel 4 menunjukkan bahwa faktor yang memengaruhi sikap petani atas peralihan fungsi lahan pertanian ke non pertanian secara signifikan adalah faktor eksternal. Faktor internal tidak memengaruhi sikap petani atas peralihan fungsi lahan pertanian ke non pertanian secara signifikan. Terbukti dari nilai T-Values yang dimiliki oleh faktor internal yakni sebesar 0,777. sementara faktor eksternal memiliki nilai T-Values sebesar 2,879. Syarat suatu variabel dikatakan signifikan adalah nilai $T$-Values lebih dari 1,64.

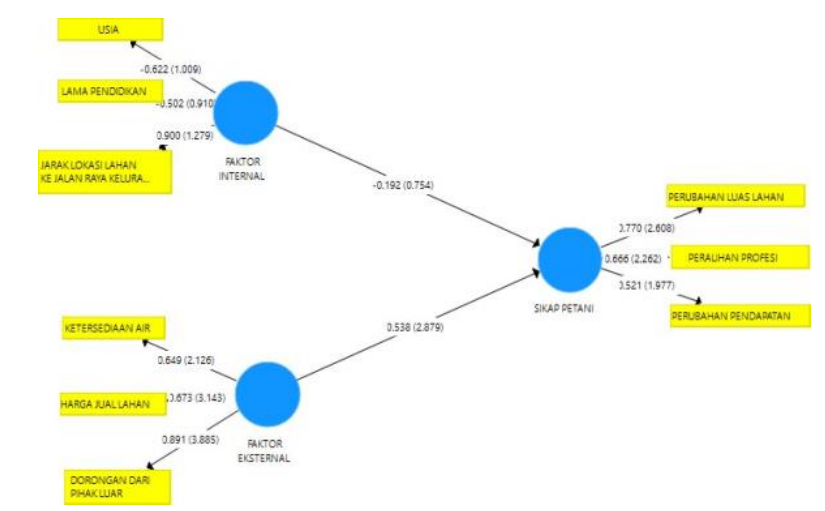

Gambar 2 Model PLS tentang faktor-faktor yang memengaruhi sikap petani atas peralihan fungsi lahan

Sikap petani atas peralihan fungsi lahan dipengaruhi oleh faktor eksternal. Hasil data kuantitatif pada Gambar 2 menunjukkan bahwa sikap petani dipengaruhi oleh faktor eksternal karena 
variabel tersebut memiliki loading factor $>0,5$. Sikap petani paling tinggi terdapat pada peralihan profesi dengan nilai loading factor 0,666 . Selain itu data kuantitatif juga menunjukkan bahwa sikap petani atas peralihan fungsi lahan tidak dipengaruhi oleh faktor internal yang dicerminkan oleh usia, lama pendidikan, dan jarak lokasi lahan ke jalan utama Kelurahan Pasir Putih. Hasil kuantitatif pada Gambar 2 menunjukkan bahwa sikap petani tidak dipengaruhi secara signifikan oleh faktor internal karena variabel tersebut memiliki loading factor $>0,5$ akan tetapi nilai $T$-Values $<1,64$. Berdasarkan uji regresi pada Gambar 2, ketersediaan air, harga jual lahan, dan dorongan dari pihak luar berpengaruh signifikan terhadap sikap petani atas peralihan fungsi lahan. Sikap petani atas peralihan fungsi lahan sangat kuat dipengaruhi oleh faktor eksternal yaitu sebesar 0,538 dengan nilai $\alpha$ sebesar 0,01 .

\section{KESIMPULAN}

Berdasarkan hasil penelitian yang telah dilakukan, terdapat beberapa kesimpulan seperti berikut ini: (1) Sikap petani responden atas peralihan fungsi lahan pertanian ke non pertanian menunjukkan bahwa sikap petani terkait perubahan luas lahan peralihan profesi, dan perubahan pendapatan paling tinggi mencapai tahapan receiving; (2) Faktor yang memengaruhi sikap petani responden atas peralihan fungsi lahan pertanian ke non pertanian yakni faktor eksternal yang dicirikan oleh ketersediaan air, harga jual lahan, dan dorongan dari pihak luar.

\section{Saran}

Berdasarkan simpulan penelitian yang diperoleh peneliti memiliki beberapa saran yang diajukan yakni: (1) Kelurahan Pasir Putih memiliki pertanian yang cukup potensial. Potensi yang dimiliki tersebut didukung dengan kondisi tanah wilayah Pasir Puth yang subur dan keinginan besar masyarakatnya untuk bertani. Sebaiknya Pemerintah Daerah Kota Depok, Dinas Ketahanan Pangan Pertanian dan Perikanan Kota Depok dapat memaksimalkan potensi pertanian yang dimiliki, yakni dengan menghidupkan kembali irigasi pertanian untuk menunjang aktivitas pertanian di Kelurahan Pasir Putih, Sawangan Depok; (2) Pembangunan perumahan di Kelurahan Pasir Putih mayoritas dibangun di atas lahan pertanian. Sebaiknya pemerintah lebih tegas dalam memberikan Izin Mendirikan Bangunan (IMB), seperti melakukan upaya sosialisasi dan terjun langsung ke lapangan untuk meninjau. Hal tersebut dilakukan sebagai upaya untuk mempertahankan lahan pertanian di Kelurahan Pasir Putih dan juga banyaknya bangunan di Kelurahan Pasir Putih yang masih belum memiliki izin untuk mendirikan bangunan. Selain itu konsistensi dari pemerintah juga diperlukan dalam mengatur RTRW Kota Depok, sehingga dapat dipetakan dengan baik wilayah-wilayah di Kota Depok sesuai dengan potensi yang dimiliki di masing-masing daerah.

\section{DAFTAR PUSTAKA}

Azwar, S. (2007). Sikap Manusia: Teori dan Pengukurannya. Yogyakarta(ID) : Pustaka Pelajar [BPS]. Badan Pusat Statistik(ID). Kecamatan Sawangan dalam Angka 2019 [Internet]. [diunduh: 26 Januari 2020]. Tersedia pada https://depokkota.bps.go.id/publication/2019/ 09/26/85075b933266b003deea3f3f/kecamata n-sawangan-dalam-angka-2019

[BPS]. Badan Pusat Statistik(ID). Kecamatan Sawangan dalam Angka 2018 [Internet]. [diunduh: 26 Januari 2020]. Tersedia pada https://depokkota.bps.go.id/publication/2018/ 09/26/ec34bfc2e5217399d5c50254/kecamata n-sawangan-dalam-angka-2018.html

[BPS]. Badan Pusat Statistik(ID). Kecamatan Sawangan dalam Angka 2016 [Internet]. [diunduh: 08 Desember 2019]. Tersedia pada https://depokkota.bps.go.id/publication/2018/ 01/04/93844622bb57e3df5e6f5ecb/kecamata n-sawangan-dalam-angka-2016

Dewi N K, Rudiarto I. 2013. Identifikasi alih fungsi lahan pertanian dan kondisi sosial ekonomi masyarakat daerah pinggiran di Kecamatan Gunungpati Kota Semarang. Jurnal Wilayah dan Lingkungan; 1(2):175-188. [internet. [diunduh pada 2019 April 23]. Tersedia pada http://digilib.mercubuana.ac.id/manager/t\%2 $\underline{1 @ \text { file_artikel_abstrak/Isi_Artikel_74193407 4305.pdf }}$ 
Irawan, Bambang. 2005. Konversi lahan sawah: potensi dampak, pola pemanfaatan, dan faktor determinan. Jurnal Forum Penelitian Agro Ekonomi; 23(1):1-18. [internet]. [diunduh pada 2019 April 23]. Tersedia pada http://ejurnal.litbang.pertanian.go.id/index.ph $\mathrm{p} /$ fae/article/view/4055

Kusdiane SD. Soetarto E, Sunito S. 2018. Alih fungsi lahan dan perubahan masyarakat di Kecamatan Cimanuk, Kabupaten Pandeglang. Jurnal Sodality; 6(3):246-251. [internet]. [diunduh pada 2019 Maret 10]. Tersedia pada http://journal.ipb.ac.id/index.php/sodalty/arti cle/view/23465

Lestari, T. 2009. Dampak Konversi Lahan Pertanian Bagi Taraf Hidup Petani. Skripsi. Bogor. Institut Pertanian Bogor.

Mugniesyah, Siti Sugiah. 2006. Modul Bahan Ajar Ilmu Penyuluhan. Bogor (ID): Institut Pertanian Bogor.

Rahmawati, Nur. 2012. Respon petani terhadap alih fungsi lahan pertanian di Desa Tamantirto Kecamatan Kasihan Kabupaten Bantul. Jurnal Ilmu-ilmu Pertanian; 21(2):13-23. [internet]. [diunduh pada 2019 Februari 18]. Tersedia pada

http://repository.umy.ac.id/handle/123456789

11511

Ridwan, I R. 2009. Faktor-faktor penyebab dan dampak konversi lahan pertanian. Jurnal Geografi GEA; 9(2): (halaman tidak diketahui). [internet]. [diunduh pada 2019 April 24]. Tersedia pada http://ejournal.upi.edu/index.php/gea/article/v iew/2448

Sarayar S, Kaunang R, dan Sondakh ML. 2016. Sikap pemilik lahan terhadap alih fungsi lahan di DesaKalasey Satu. Jurnal Agri-SosioEkonomi; 12(3A):47-66. [internet]. [diunduh pada 2019 Maret 10]. Tersedia pada https://ejournal.unsrat.ac.id/index.php/jisep/a rticle/view/14286/0

Saefulhalim RS, Lutfi IN. 1995. Kebijaksanaan Pengendalian Konversi Lahan Sawah Beririgasi Teknis. Makalah Seminar Pengembangan Sumberdaya Lahan. Pusat Penelitian Tanah dan Agroklimat. Bogor 26- 27 September 1995.

Setiawan, H P. 2016. Alih fungsi (konversi) lahan pertanian ke non pertanian kasus di Kelurahan Simpang Pasir Kecamatan Palaran Kota Samarinda. eJournal Sosiatri-Sosiologi; 4(2):280-293. [internet]. [diunduh pada 2019 April 10]. Tersedia pada https://ejournal.sos.fisip- unmul.ac.id/site/?p=883

Singarimbun M dan Effendi S. 1989. Metode Penelitian Survey. Jakarta (ID): LP3ES

Siswanto, Eddy. 2007. Kajian harga lahan dan lokasi lahan permukiman di Kecamatan Arga Makmur, Kabupaten Bengkulu Barat. [tesis]. Semarang (ID): Universitas Diponegoro.

Sumaryanto, Sudaryanto T. 2005. Pemahaman Dampak Negatif Konversi Lahan Sawah Sebagai Landasan Perumusan Strategi Pengendaliannya. Prosiding Seminar Penanganan Konversi Lahan dan Pencapaian Pertanian Abadi. LPPM IPB. Bogor.

Sunartomo, Aryo Fajar. 2015. Perkembangan konversi lahan di Kabupaten Jember. Jurnal Agriekonomika; 4(1):22-36. [internet]. [diunduh pada 2019 April 24]. Tersedia pada http://journal.trunojoyo.ac.id/agriekonomika/ article/view/671/591

Undang Undang nomor 41 tahun 2009 tentang perlindungan lahan pertanian pangan berkelanjutan

Wiraraja I G J, Windia I W, dan Sudarta I W. 2016. Dampak alih fungsi lahan sawah petani pemilik terhadap kehidupan rumah tangganya (ttudi kasus di Subak Lange, di Kawasan Desa Pemecutan Kelod, Kecamatan Denpasar Barat). E-Jurnal Agribisnis dan Agrowisata; 5(2):468-477. [internet]. [diunduh pada 2019 Februari 26].

Tersedia pada http://ojs.unud.ac.id/index.php/JAA 